Creative Commons User License: CC BY-NC-ND

Abstracted by: EBSCOhost, Electronic Journals Service (EJS), Google Scholar, Journal Seek, Scientific Commons,

Food and Agricultural Organization (FAO), CABI and Scopus
Journal of Agricultural Extension

Vol. 24 (1) January, 2020

ISSN(e): 24086851; ISSN(Print); 1119944X

http://journal.aesonnigeria.org

http://www.ajol.info/index.php/jae

Email: editorinchief@aesonnigeria.org

\title{
Adoption of Mobile Phone for Marketing of Cereals by Smallholder Farmers in Quang Dien District of Vietnam
}

\author{
https://dx.doi.org/10.4314/jae.v24i1.11
}

\section{Hoang, Gia Hung}

Hue University of Agriculture and Forestry

Hue University, Vietnam

Email: hghung@hueuni.edu.vn, +840899878951

\begin{abstract}
The study investigated factors that shape the Vietnamese smallholders' adoption of mobile phones for marketing. A random sample of 161 smallholders was drawn from a total of 275 smallholders who produced and marketed cereals in Quang Dien district of Vietnam. Percentages, means, standard deviations, chi squares test, $t$-test and a binary logistic regression model were applied to analyse the data. This study concluded that the young male smallholders with a higher education level, who are members of community-based organisations (CBOs) and live far from an electricity base, have high income and participate in credit programs, have a greater tendency to adopt mobile phones for marketing. Lack of knowledge/skills on use of applications on mobile phones, together with language barriers and mobile phone network problems hindered smallholder adoption of mobile phones for marketing.
\end{abstract}

Key words: mobile phones, adoption, marketing, smallholders, Quang Dien district.

\section{Introduction}

Agriculture plays a key role in social and economic development in developing nations. Small-scale farms often dominate the agricultural sectors in the developing world within the Pacific, Asia and Africa (Lowder, Skoet, \& Raney, 2016). However, smallholders in developing countries such as Vietnam are struggling with difficulties in accessing knowledge, skills and marketing information that could improve their income (Chapagain \& Raizada, 2017; Misaki, Apiola, \& Gaiani, 2016; Misaki, Apiola, Gaiani, \& Tedre, 2018). Keeping smallholders more informed about marketing information is considered a significant means to improve the smallholders' income (Wyche \& Steinfield, 2016). Information and Communication Technologies (ICTs) such as TV, mobile phones, radio and internet systems can be an important means of making smallholders more informed about marketing information because ICTs can enable the smallholders access to timely and accurate information that they need when making important decisions. Several researchers (Chikuni \& Kilima, 2019; Razaque \& Sallah, 2013; Zhang, Wang, \& Duan, 2016) suggest that the adoption of ICTs such as mobile phones improved the bargaining power of farmers and enhanced communication among the farmers. Some scholars (Alavion \& Allahyari, 2012; Bachaspati, 2018; Goyal \& González-Velosa, 2013) also claimed 
Creative Commons User License: CC BY-NC-ND

Abstracted by: EBSCOhost, Electronic Journals Service (EJS), Google Scholar, Journal Seek, Scientific Commons,

Food and Agricultural Organization (FAO), CABI and Scopus
Journal of Agricultural Extension

Vol. 24 (1) January, 2020

ISSN(e): 24086851; ISSN(Print); 1119944X

http://journal.aesonnigeria.org

http://www.ajol.info/index.php/jae

Email: editorinchief@aesonnigeria.org

that the use of ICTs for marketing by farmers contributes by removing intermediaries, reducing transaction costs and helping them find potential customers.

According to the General Statistics Office of Vietnam (GSO) (2018), although the agricultural sector of Vietnam accounted for about $16.5 \%$ GDP of the country in 2017 , it employed more than $69 \%$ of the labour force. The sector was dominated by about 10 million smallholders in 2017 (GSO, 2018). Although the Government of Vietnam (GOV) has strongly promoted the use of ICTs over the last decade to facilitate the country's development, the use of ICTs by Vietnamese smallholders for marketing is very limited (VietNamNews, 2017). In order to facilitate smallholders' adoption of ICTs for marketing, it is important to understand the factors that influence its adoption.

Existing literatures (Abebe \& Mammo Cherinet, 2018; Alavion, Allahyari, Al-Rimawi, \& Surujlal, 2017; Kante, Oboko, \& Chepken, 2017; Mittal \& Mehar, 2016) reveal that the farmers' adoption of ICTs is likely to be connected to either one, or more, of the following factors.

a) Demographic factors of farmers such as gender, age and education level (Das, 2014; Mittal \& Mehar, 2016; Senthilkumar, Chander, Pandian, \& Kumar, 2013);

b) Socio-economic factors of farmers and farms such as farm size, income and access to credit (Ogutu, Okello, \& Otieno, 2014; Senthilkumar et al., 2013);

c) Situational factors of farmers and farms such as distance from farmers' home to local markets (Abebe \& Mammo Cherinet, 2018); and

d) Institutional factors of farmers such as farmers' participation in training courses and extension contacts by farmers (Abebe \& Mammo Cherinet, 2018; Senthilkumar et al., 2013).

However, limited studies have examined the combination of the factors mentioned in relation to the smallholders' adoption of ICTs for marketing, especially the smallholders' adoption of mobile phones for marketing. In addition, no known study has investigated factors influencing the adoption of mobile phones for marketing by Vietnamese smallholders. Moreover, the findings reported in the existing literature (Alavion et al., 2017; Kante et al., 2017; Mittal \& Mehar, 2016; Ogutu et al., 2014; Senthilkumar et al., 2013; Zhang et al., 2016) are not consistent across the studies. For example, Mittal and Mehar (2016) investigated factors that influence the farmers' adoption of ICTs for marketing in India and found that Indian farmers with higher education level and large farm size tended to use ICTs for marketing more than those with a lower education level and small farm size. Applying the same research approach as Mittal and Mehar (2016), Abebe and Mammo Cherinet (2018) examined the farmers' use of ICTs for marketing in Ethiopia and found that Ethiopian farmers who are more educated and well-trained have a greater tendency to use ICTs for marketing than those who are not. However, the authors found that farm size had no effect on the use of ICTs for marketing, which is similar to Ogutu et al. (2014) findings. Taking all together, the farmers' adoption of ICTs for marketing is contextdependent. The main purpose of this study was to examine factors that affect the 
Creative Commons User License: CC BY-NC-ND

Abstracted by: EBSCOhost, Electronic Journals Service (EJS), Google Scholar, Journal Seek, Scientific Commons,

Food and Agricultural Organization (FAO), CABI and Scopus
Journal of Agricultural Extension

Vol. 24 (1) January, 2020

ISSN(e): 24086851; ISSN(Print); 1119944X

http://journal.aesonnigeria.org

http://www.ajol.info/index.php/jae

Email: editorinchief@aesonnigeria.org

adoption of mobile phones by cereal Vietnamese smallholders for marketing. The specific objectives of this study were:

(1) to determine the extent of smallholders' use of ICTs for marketing; and

(2) to determine factors that affect the adoption of mobile phone for marketing by smallholders and identify challenges in using mobile phones for marketing.

\section{Methodology}

This study was conducted in Quang Dien, which is a rural district in Thua Thien Hue province of Vietnam, lies between 16.0 to 16.8 North latitude and 107.7 to 108.2 East longitude (Figure 1). The district comprises $163.05 \mathrm{~km}^{2}$ (16.3045 thousand ha) (Quang Dien District Statistical Office, 2019). The gross output of the district in 2018 was 2.3 trillion VND ( 95 million USD). The agricultural sector accounted for $40 \%$ of the gross output of the district in 2018 (Quang Dien District Statistical Office, 2019). About $86 \%$ of the population live in rural areas and are engaged in agricultural activities (Quang Dien District Statistical Office, 2019).Cropping is the most important contributor to agricultural activity. The recent official statistics show that crops accounted for $46.5 \%$ of the total gross output from agriculture in 2018 (Quang Dien District Statistical Office, 2019). In 2018, the gross output of annual crops accounted for $97.5 \%$ of the total gross output from crops (Quang Dien District Statistical Office, 2019). Main crops in the district include rice, maize, sweet potato, peanuts.

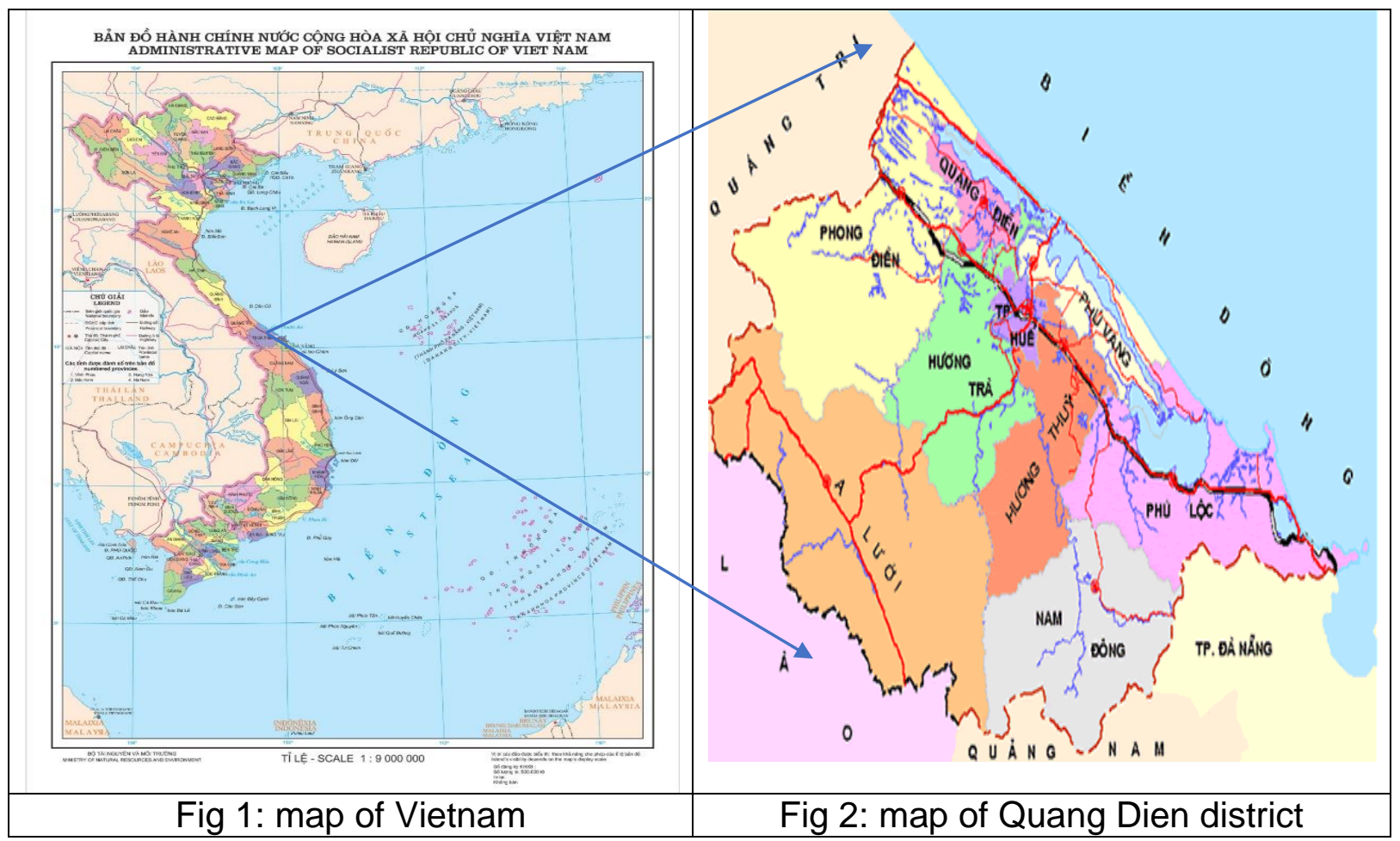

A sample size of 161 cereal smallholders were randomly selected from a total population of 275 cereal smallholders in Quang Dien district. A two-section, 
Creative Commons User License: CC BY-NC-ND

Abstracted by: EBSCOhost, Electronic Journals Service (EJS), Google Scholar, Journal Seek, Scientific Commons,

Food and Agricultural Organization (FAO), CABI and Scopus
Journal of Agricultural Extension

Vol. 24 (1) January, 2020

ISSN(e): 24086851; ISSN(Print); 1119944X

http://journal.aesonnigeria.org

http://www.ajol.info/index.php/jae

Email: editorinchief@aesonnigeria.org

structured interview schedule was used to collect data. The first section consists of statements on: (1) types of cereals produced and marketed, prices of selling the cereals; (2) sources of marketing information, farmer ICT use; (3) the extent of use of ICTs for marketing. The extent of use of ICTs was measured on a five-point Likert scale, which ranged from "never use" to "very often use"; and (4) difficulties when using ICTs. The second part gathered demo-economic, situational and institutional information. The interview schedule was pre-tested with five smallholders and reviewed by a panel of experts for face and content validity.

Data were analysed using IBM-SPSS statistical package. Percentages, means and standard deviations were used. Chi squares test for dummy variables by ICT use and a T-test for continuous variables were applied to identify the relationships between independent variables associated with the adoption of mobile phones for marketing. Multicollinearity among the variables was checked. A binary logistic regression model was used to determine the effect of the independent variables on the dependent variable (Mukherjee, Sinha, \& Chattopadhyay, 2018). The dependent variable is a dummy variable which takes a value of 1 for ICT user and 0 otherwise. Table 1 describes the characteristics of hypothesised dependent and independent variables in the adoption of ICTs for marketing.

Table 1. Hypothesized variables in the use of ICTs for marketing

\begin{tabular}{|c|c|c|}
\hline Description & Category & Measurement \\
\hline \multicolumn{3}{|c|}{ Dependent variables } \\
\hline Use of ICTs for marketing & Dummy & 1 = User; \\
\hline & & $0=$ Non-user \\
\hline \multicolumn{3}{|c|}{ Independent variables } \\
\hline Age of smallholders & Continuous & Years \\
\hline Level of smallholders' education & Continuous & Years \\
\hline Distance from local markets & Continuous & $\mathrm{Km}$ \\
\hline Distance from electricity base & Continuous & $\mathrm{Km}$ \\
\hline Farm size & Continuous & $\mathrm{Ha}$ \\
\hline Total annual income & Continuous & VND $^{1}$ \\
\hline Gender of smallholders & Dummy & $1=$ male $; 0=$ female \\
\hline $\begin{array}{l}\text { Smallholders' participation in credit } \\
\text { programs }\end{array}$ & Dummy & $1=$ yes; 0 = no \\
\hline $\begin{array}{l}\text { Smallholders' participation in training } \\
\text { programs }\end{array}$ & Dummy & 1 = yes; 0 = no \\
\hline
\end{tabular}

$1:$ VND is Vietnamese dong. About 22.000 VND $=1$ USD. 
Creative Commons User License: CC BY-NC-ND

Abstracted by: EBSCOhost, Electronic Journals Service (EJS), Google Scholar, Journal Seek, Scientific Commons,

Food and Agricultural Organization (FAO), CABI and Scopus
Journal of Agricultural Extension

Vol. 24 (1) January, 2020

ISSN(e): 24086851; ISSN(Print); 1119944X

http://journal.aesonnigeria.org

http://www.ajol.info/index.php/iae

Email: editorinchief@aesonnigeria.org

http://eoi.citefactor.org/10.11226/v23i4

$1=$ yes; 0 = no

\section{Results and Discussion}

\section{Smallholders Cereal Farmers Sources of Marketing Information}

Table 2 reports smallholders' sources of marketing information. Overall, cereal smallholders sought marketing information from many sources. The majority $(86.8 \%)$ of smallholder cereal farmers sourced information from collectors/traders. Similarly, neighbours/friends $(55.3 \%)$, mobile phones $(41.5 \%)$, other producers $(27.0 \%)$ and farmers union $(22.6 \%)$ were other major sources of marketing information to smallholder cereal farmers. About $12.0 \%$ of the smallholder farmers reported getting marketing information through a women's union while $10.1 \%$ and $5.7 \%$ sourced market information from extension officers and co-operatives respectively. The results of this study reveal that cereal smallholders seek marketing information from several sources which may be complementary. This suggests that any single source of information does not provide all of the information needs of the smallholder cereal farmers for marketing. Some studies (Alavion et al., 2017; Das, 2014; Mittal \& Mehar, 2016) found that smallholders did not rely on a single source of information for marketing, but used a number of sources, which is consistent with the result of this study.

Table 2: Smallholder cereal farmers' sources of market information

\section{Sources of marketing information Percent of Cases (\%) $(n=161)$}

\begin{tabular}{lc}
\hline Collectors & 86.8 \\
Neighbours/friends & 55.3 \\
Mobile phone & 41.5 \\
Other producers & 27.0 \\
Farmer union & 22.6 \\
Women union & 11.9 \\
Extensionists & 10.1 \\
Cooperatives & 5.7
\end{tabular}

\section{Extent of Smallholders' Use of Mobile Phone for Marketing}

Table 3 shows the extent of smallholder cereal farmers' use of mobile phone for marketing. About $43 \%$ (69) and more than $26 \%$ (42) of smallholders reported using mobile phones for marketing as "often" and "very often" respectively. Number of smallholders reported not using mobile phones to market produce was $26.1 \%$. This

2 : Community-based organisations (CBOs). 
Creative Commons User License: CC BY-NC-ND

Abstracted by: EBSCOhost, Electronic Journals Service (EJS), Google Scholar, Journal Seek, Scientific Commons,

Food and Agricultural Organization (FAO), CABI and Scopus
Journal of Agricultural Extension

Vol. 24 (1) January, 2020

ISSN(e): 24086851; ISSN(Print); 1119944X

http://journal.aesonnigeria.org

http://www.ajol.info/index.php/iae

Email: editorinchief@aesonnigeria.org

result suggests that mobile phone is one of key ICT tools used by most smallholders for marketing of cereals. The results of this study can be supported from Toluwase and Apata (2017) findings who found that $9.2 \%$ and $44.2 \%$ of Nigerian farmers use mobile phones for accessing agricultural information as "very frequently" and "frequently" respectively.

Table 3: Extent of smallholders' use of mobile phones for marketing

\begin{tabular}{lc}
\hline Extent of mobile phone use & Percentage (\%) \\
\hline Never & 26.1 \\
Rarely & 1.9 \\
Sometimes & 3.1 \\
Often & 42.9 \\
Very often & 26.1 \\
\hline
\end{tabular}

\section{Relationships Between Smallholders' Characteristics and Mobile Phone Use for Marketing}

Table 4 shows that the smallholders' use of mobile phone for marketing was statistically associated with their gender, credit program participation, training course participation and CBO participation at $p \leq 0.01$. The T-test results in Table 5 reveals that the smallholders' use of mobile phone for marketing was statistically associated with their age, education level and income at $p \leq 0.01$ and with distance from their home to electricity base at $p \leq 0.05$. This means that the difference of characteristics of smallholder farmers influences their use of mobile phone for marketing of cereals. Findings from previous studies (Aldosari, Al Shunaifi, Ullah, Muddassir, \& Noor, 2019; Das, 2014; Mittal \& Mehar, 2016) suggest that socio-economic characteristics of farmers influence their behaviours in choosing use of ICT tools for accessing agricultural information, which is corroborated by this research.

Table 4: Mobile phone use for marketing

\begin{tabular}{|c|c|c|c|c|c|}
\hline Variables & & Total (\%) & $\begin{array}{c}\text { Mobile phone } \\
\text { users (\%) }\end{array}$ & $\begin{array}{c}\text { Non-mobile } \\
\text { phone users (\%) }\end{array}$ & Chi-squares test \\
\hline \multirow[t]{2}{*}{ Gender } & Female & 34.8 & 18.0 & 16.8 & $13.89^{* * * 3}$ \\
\hline & Male & 65.2 & 52.2 & 13.0 & \\
\hline Credit & No & 52.2 & 29.8 & 22.4 & $14.28^{* * *}$ \\
\hline participation & Yes & 47.8 & 40.4 & 7.5 & \\
\hline Training & No & 31.1 & 17.4 & 13.7 & $6.97^{\star \star \star}$ \\
\hline participation & Yes & 68.9 & 52.8 & 16.1 & \\
\hline CBO & No & 32.3 & 15.5 & 16.8 & $17.94^{\star * *}$ \\
\hline participation & Yes & 67.7 & 54.7 & 13.0 & \\
\hline
\end{tabular}

${ }^{* * *} P \leq 0.01$ 
Creative Commons User License: CC BY-NC-ND

Abstracted by: EBSCOhost, Electronic Journals Service (EJS), Google Scholar, Journal Seek, Scientific Commons,

Food and Agricultural Organization (FAO), CABI and Scopus

http://eoi.citefactor.org/10.11226/v23i4
Journal of Agricultural Extension

Vol. 24 (1) January, 2020

ISSN(e): 24086851; ISSN(Print); 1119944X

http://journal.aesonnigeria.org

http://www.ajol.info/index.php/jae

Email: editorinchief@aesonnigeria.org

Table 5: T-test for continuous variables by mobile phone use for marketing

\begin{tabular}{lccccc}
\hline Variables & \multicolumn{2}{c}{ Mobile phone users } & \multicolumn{2}{c}{$\begin{array}{c}\text { Non-mobile phone } \\
\text { users }\end{array}$} & t-value \\
& Mean & Std. Dev. & Mean & Std. Dev. & \\
\hline Age & 3.75 & 1.14 & 4.66 & 1.20 & $-4.55^{\star * *}$ \\
Level of education & 3.30 & 0.98 & 2.50 & 0.96 & $4.72^{* * *}$ \\
Distance from local markets & 1.98 & 1.59 & 1.61 & 1.15 & $1.43^{\text {NS4 }}$ \\
Distance from electricity base & 2.56 & 3.34 & 1.43 & 2.33 & $2.44^{* * 5}$ \\
Farm size & 4.90 & 2.61 & 4.68 & 1.54 & $0.67^{\text {NS }}$ \\
Income & 4.28 & 1.26 & 3.43 & 1.48 & $3.68^{* * *}$ \\
\hline
\end{tabular}

\section{Prices of Cereals Marketed by Smallholder Farmers}

Table 6 reveals variation in prices when marketing cereals between mobile phone users and non-mobile phone users. Generally, cereal smallholders using mobile phones were selling their produce at a higher price than those who did not use mobile phones. Importantly, T-test results in Table 6 show a statistically significant difference in average price per one $\mathrm{kg}$ of rice and maize at a significance level $\mathrm{p} \leq$ 0.01 and a statistically significant difference in average price of peanut at a significance level $p \leq 0.05$. This could be attributed to access to marketing information. The results of this study suggest that smallholders' use of mobile phone for marketing has a positive impact on selling price of cereals. The results of this study partially support Tadesse and Bahiigwa (2015) findings who investigated the use of mobile phone and farmers' marketing decision and found that Ethiopian farmers with mobile phones receive higher selling prices for Teff and Maize, but it was not statistically significant.

Table 6: Variation in prices of cereals marketed by smallholders

\begin{tabular}{lcccc}
\hline $\begin{array}{l}\text { Agricultural } \\
\text { produce }\end{array}$ & Mobile phone users & $\begin{array}{c}\text { Average price in VND/kg } \\
\text { Non-mobile phone } \\
\text { users }\end{array}$ & Mean difference & t-value \\
\hline Rice & $6,647.34$ & $6,439.58$ & 207.76 & $3.23^{* * *}$ \\
Maize & $7,519.51$ & $6,617.64$ & 901.86 & $5.41^{* * *}$ \\
Sweet potato & $5,886.66$ & $5,545.45$ & 341.21 & 0.75 \\
Peanut & $17,458.13$ & $15,914.28$ & $1,543.85$ & $2.02^{*}$ \\
\hline${ }^{*} p \leq 0.1,{ }^{* *} p \leq 0.05$ & & & &
\end{tabular}


Creative Commons User License: CC BY-NC-ND

Abstracted by: EBSCOhost, Electronic Journals Service (EJS), Google Scholar, Journal Seek, Scientific Commons,

Food and Agricultural Organization (FAO), CABI and Scopus
Journal of Agricultural Extension

Vol. 24 (1) January, 2020

ISSN(e): 24086851; ISSN(Print); 1119944X

http://journal.aesonnigeria.org

http://www.ajol.info/index.php/iae

Email: editorinchief@aesonnigeria.org

\section{Factors Affecting Mobile Phone Use for Marketing by Smallholders}

Table 7 shows an estimation of logistic regression model output for mobile phone use for marketing. Among the ten independent variables analysed, seven variables were found to be statistically significant and affecting mobile phone use for marketing. Smallholders' age, gender, level of education, income, smallholders' participation in CBOs, smallholders' participation in credit programs and distance from smallholders' home to electricity base were found to be statistically significant. It was found that the adoption of mobile phones for marketing was negatively, statistically associated with age of smallholders. Some researchers (Das, 2014; Mittal \& Mehar, 2016; Senthilkumar et al., 2013) suggest that young smallholders tend to be ICT users, which is corroborated findings by this research. However, it was found that the adoption of mobile phones for marketing was positively associated with the distance from smallholders' homes to the electricity base, which is not consistent with Abebe and Mammo Cherinet (2018) findings, who found that the use of ICTs for marketing by Ethiopian smallholders was negatively associated with the distance from home to the electricity base.

Interestingly, this study found that the adoption of mobile phones for marketing was significantly affected by whether or not smallholders were members of CBOs. Smallholders who are a member of CBOs tend to be ICT users more so than those who are not. The possible reason for this is that CBO members often support each other in terms of human and financial resources, and this can lead to being in a better position to adopt mobile phones for marketing, as well as sharing information between members. In the mainstream literature (Alavion et al., 2017; Kante et al., 2017; Mittal \& Mehar, 2016; Ogutu et al., 2014; Senthilkumar et al., 2013), little has been written about the importance and impact of membership of $\mathrm{CBO}$ s on smallholders' mobile phone adoption for marketing.

The adoption of mobile phones for marketing was positively, statistically associated with smallholders' education level. The findings from this study are generally consistent with findings reported in the literature (Abebe \& Mammo Cherinet, 2018; Alavion et al., 2017; Mittal \& Mehar, 2016) that smallholders who are at a higher education level tended to be ICT adopters. The adoption of mobile phones for marketing was positively and significantly associated with gender and income. It was found that male smallholders were in a better position to use mobile phone for marketing than female smallholders. This can be explained as follows; in rural Vietnamese communities, men often have more freedom to move about to get agricultural information and this may likely affect their adoption of mobile phones. 
Creative Commons User License: CC BY-NC-ND

Abstracted by: EBSCOhost, Electronic Journals Service (EJS), Google Scholar, Journal Seek, Scientific Commons,

Food and Agricultural Organization (FAO), CABI and Scopus
Journal of Agricultural Extension

Vol. 24 (1) January, 2020

ISSN(e): 24086851; ISSN(Print); 1119944X

http://journal.aesonnigeria.org

http://www.ajol.info/index.php/iae

Email: editorinchief@aesonnigeria.org

Table 7: Estimation of regression model for mobile phone use for marketing

\begin{tabular}{lcc}
\hline \multicolumn{1}{c}{ Variables } & Coefficient & Std. Err. \\
\hline Age of smallholders & $-0.635^{\star * *}$ & 0.219 \\
Level of smallholders' education & $0.769^{\star *}$ & 0.301 \\
Distance from local markets & $0.272^{\mathrm{NS}}$ & 0.185 \\
Distance from electricity base & $0.161^{*}$ & 0.090 \\
Farm size & $0.075^{\mathrm{NS}}$ & 0.125 \\
Total annual income & $0.383^{\star *}$ & 0.186 \\
Gender of smallholders & $1.047^{\star *}$ & 0.504 \\
Smallholders' participation in credit programs & $1.071^{\star *}$ & 0.505 \\
Smallholders' participation in training programs & $0.278^{\mathrm{NS}}$ & 0.531 \\
Smallholders' participation in CBO & $1.747^{\star * *}$ & 0.515 \\
Constant & $-3.663^{* *}$ & 1.699 \\
\hline
\end{tabular}

${ }^{*} p \leq 0.1,{ }^{* *} p \leq 0.05,{ }^{* * *} p \leq 0.01$, Number of observations $=161$

LR chi square $(11)=79.51^{* * *}$, Log likelihood $=116.66$.

\section{Difficulties in the Use of Mobile Phone for Marketing}

Table 8 shows the difficulties in using mobile phones for marketing by smallholder cereal farmers. The main difficulties that hinder the use of mobile phones by smallholder cereal farmers for marketing were lack of knowledge/skills to use applications on mobile phones $(72.0 \%)$, followed by language barriers $(37.3 \%)$, mobile phone network problems $(34.8 \%)$, high cost of using mobile phones $(24.8 \%)$ and ignorance of mobile phones use (24.8\%). Poor quality battery $(21.7 \%)$ and lack of money to buy mobile phones $(27.4 \%)$ were also difficulties encountered by smallholder cereal farmers when using mobile phones for cereal marketing. In a study on the use of ICTs for marketing by Ethiopian farmers, Abebe and Mammo Cherinet (2018) found that difficulty in charging mobile phones due to unavailability of electric power and high cost of buying mobile phones were the main difficulties Ethiopian farmers faced when using mobile phones for marketing, which are not consistent with this study. The result of this study suggests that the district agricultural extension department, communication officers and development agents should provide training and orientation to farmers about using mobile phones for marketing of cereals, particularly on how to use applications on mobile phones. 
Creative Commons User License: CC BY-NC-ND

Abstracted by: EBSCOhost, Electronic Journals Service (EJS), Google Scholar, Journal Seek, Scientific Commons,

Food and Agricultural Organization (FAO), CABI and Scopus
Journal of Agricultural Extension

Vol. 24 (1) January, 2020

ISSN(e): 24086851; ISSN(Print); 1119944X

http://journal.aesonnigeria.org

http://www.ajol.info/index.php/iae

Email: editorinchief@aesonnigeria.org

Table 8: Difficulties in using mobile phone for marketing

\begin{tabular}{lc}
\hline Difficulties in using mobile phones & Percent of Cases (\%) \\
\hline Lack of knowledge using mobile phones & 72.0 \\
Language barriers & 37.3 \\
Mobile phone network problems & 34.8 \\
High cost of using mobile phones & 24.8 \\
Do not know how to use mobile phones & 24.8 \\
Poor quality battery of mobile phones & 21.7 \\
Lack of money to buy mobile phones & 17.4 \\
\hline
\end{tabular}

\section{Conclusions and Recommendations}

Young male smallholders with a higher education level are in a better position to use mobile phones for marketing than older, and less educated female smallholders. Smallholders who live far from the electricity base tend to be mobile phone users compared to those who live close to one. A farmer who had a high income tends to be a mobile phone user compared to those who had a low income. Importantly, smallholders who participate in credit programs and are members of CBOs are better mobile phone users than those who do not take part in the credit programs and are not members of CBOs. Lack of knowledge/skills to use applications on mobile phones, together with language barriers and mobile phone network problems are hindering cereal smallholders in their adopting mobile phones for marketing. Improving education, providing credit services, developing and sustaining CBOs for rural smallholders could be the way to facilitate the adoption of mobile phones by smallholders.

\section{Acknowledgement}

The author of this research would like to thank Hue University for its financial support in conducting this research.

\section{References}

Abebe, A., \& Mammo Cherinet, Y. (2018). Factors Affecting the Use of Information and Communication Technologies for Cereal Marketing in Ethiopia. Journal of Agricultural \& Food Information, 20(1), 59-70.

Alavion, S. J., \& Allahyari, M. S. (2012). An overview of the electronic agricultural studies in trading and marketing sections. Management Agricol, 14(2), 123-132.

Alavion, S. J., Allahyari, M. S., Al-Rimawi, A. S., \& Surujlal, J. (2017). Adoption of agricultural E-marketing: application of the theory of planned behavior. Journal of International Food \& Agribusiness Marketing, 29(1), 1-15.

Aldosari, F., Al Shunaifi, M. S., Ullah, M. A., Muddassir, M., \& Noor, M. A. (2019). Farmers' perceptions regarding the use of Information and Communication Technology (ICT) 
Creative Commons User License: CC BY-NC-ND

Abstracted by: EBSCOhost, Electronic Journals Service (EJS), Google Scholar, Journal Seek, Scientific Commons,

Food and Agricultural Organization (FAO), CABI and Scopus
Journal of Agricultural Extension

Vol. 24 (1) January, 2020

ISSN(e): 24086851; ISSN(Print); 1119944X

http://journal.aesonnigeria.org

http://www.ajol.info/index.php/iae

Email: editorinchief@aesonnigeria.org

in Khyber Pakhtunkhwa, Northern Pakistan. Journal of the Saudi Society of Agricultural Sciences, 18(2), 211-217.

Bachaspati, S. (2018). An economics study of electronic trading portal for national agriculture market (e-NAM) on selected agrcultural produce market committtees (APMCs) of Chhattisgarh. (Master thesis), Indira Gandhi Krishi Vishwavidhyalaya, Raipur, India. Retrieved from http://krishikosh.egranth.ac.in/bitstream/1/5810063093/1/Soham\%20Bachaspati.pdf

Chapagain, T., \& Raizada, M. N. (2017). Agronomic Challenges and Opportunities for Smallholder Terrace Agriculture in Developing Countries. Frontiers in plant science, 8(March 2017), 331-331.

Chikuni, T., \& Kilima, F. T. M. (2019). Smallholder farmers' market participation and mobile phone-based market information services in Lilongwe, Malawi. The Electronic Journal of Information Systems in Developing Countries, 85(6), 1-13.

Das, B. (2014). ICTs Adoption for Accessing Agricultural Information: Evidence from Indian Agriculture. Agricultural Economics Research Review, 27(2), 199-208.

Goyal, A., \& González-Velosa, C. (2013). Improving Agricultural Productivity and Market Efficiency in Latin America and the Caribbean: How ICTs can make a Difference? Journal of Reviews on Global Economics, 2(2013), 172-182.

GSO. (2018). Statistical Yearbook of Vietnam. Hanoi, Vietnam: Statistical Publishing House.

Kante, M., Oboko, R., \& Chepken, C. (2017). Influence of Perception and Quality of ICT-Based Agricultural Input Information on Use of ICTs by Farmers in Developing Countries: Case of Sikasso in Mali. The Electronic Journal of Information Systems in Developing Countries, 83(1), 1-21.

Lowder, S. K., Skoet, J., \& Raney, T. (2016). The number, size, and distribution of farms, smallholder farms, and family farms worldwide. World Development, 87(November 2016), 16-29.

Misaki, E., Apiola, M., \& Gaiani, S. (2016). Technology for small scale farmers in Tanzania: a design science research approach. The Electronic Journal of Information Systems in Developing Countries, 74(1), 1-15.

Misaki, E., Apiola, M., Gaiani, S., \& Tedre, M. (2018). Challenges facing sub-Saharan small-scale farmers in accessing farming information through mobile phones: A systematic literature review. The Electronic Journal of Information Systems in Developing Countries, 84(4), 1-12.

Mittal, S., \& Mehar, M. (2016). Socio-economic Factors Affecting Adoption of Modern Information and Communication Technology by Farmers in India: Analysis Using Multivariate Probit Model. The Journal of Agricultural Education and Extension, 22(2), 199-212.

Mukherjee, S., Sinha, B. K., \& Chattopadhyay, A. K. (2018). Statistical Methods in Social Science Research. Singapore: Springer.

Ogutu, S. O., Okello, J. J., \& Otieno, D. J. (2014). Impact of information and communication technology-based market information services on smallholder farm input use and productivity: The case of Kenya. World Development, 64(December 2014), 311-321. 
Creative Commons User License: CC BY-NC-ND

Abstracted by: EBSCOhost, Electronic Journals Service (EJS), Google Scholar, Journal Seek, Scientific Commons,

Food and Agricultural Organization (FAO), CABI and Scopus
Journal of Agricultural Extension

Vol. 24 (1) January, 2020

ISSN(e): 24086851; ISSN(Print); 1119944X

http://journal.aesonnigeria.org

http://www.ajol.info/index.php/iae

Email: editorinchief@aesonnigeria.org

Quang Dien District Statistical Office. (2019). Statistical Yearbook of Quang Dien District. Quang Dien District, Thua Thien Hue, Vietnam: The Quang Dien District Department of Statistics.

Razaque, A., \& Sallah, M. (2013). The use of mobile phone among farmers for agriculture development. International Journal of Scientific Research, 2(6), 95-98.

Senthilkumar, S., Chander, M., Pandian, A. S. S., \& Kumar, N. S. (2013). Factors associated with utilization of ICT enabled Village Information Centres by the dairy farmers in India: The case of Tamil Nadu. Computers and Electronics in Agriculture, 98(October 2013), 81-84.

Tadesse, G., \& Bahiigwa, G. (2015). Mobile Phones and Farmers' Marketing Decisions in Ethiopia. World Development, 68(April 2015), 296-307.

Toluwase, S., \& Apata, O. (2017). Use of ICTs as a Source of Information for Improving Agricultural Productivity in South-West, Nigeria. International Journal of Agricultural Economics, 2(3), 50-54.

VietNamNews. (2017). VN needs to enhance ICT application in agriculture. Retrieved from https://vietnamnews.vn/economy/416039/vn-needs-to-enhance-ict-application-inagriculture.html\#K50F3sECEmRVfigA.97

Wyche, S., \& Steinfield, C. (2016). Why don't farmers use cell phones to access market prices? Technology affordances and barriers to market information services adoption in rural Kenya. Information Technology for Development, 22(2), 320-333.

Zhang, Y., Wang, L., \& Duan, Y. (2016). Agricultural information dissemination using ICTs: A review and analysis of information dissemination models in China. Information Processing in Agriculture, 3(1), 17-29. 